\title{
What's in a name? Context-dependent significance of 'global' methylation measures in human health and disease
}

Regan Vryer ${ }^{1,2}$ and Richard Saffery ${ }^{1,2^{*}}$

\begin{abstract}
/summary
The study of DNA methylation in development and disease has 'exploded' as a field in recent years, with three major classes of measurement now routine. These encompass (i) locus-specific, (ii) genome-scale/wide and (iii) 'global' methylation approaches. Measures of global methylation refer to the level of 5-methylcytosine ( $5 \mathrm{mC})$ content in a sample relative to total cytosine. Despite this, several other measures are often referred to as 'global', with the underlying assumption that they accurately reflect $5 \mathrm{mC}$ content. The two most common surrogate, or proxy, measures include generating a mean or median methylation value from (i) the average measure in thousands of highly repetitive genomic elements and (ii) many thousands to several million primarily unique $\mathrm{CpG}$ sites throughout the genome. Numerous lines of evidence suggest the underlying assumption of equivalence of these measures is flawed, with considerable variation in the regulation of different 'flavours' of DNA methylation throughout the genome depending on cell type, differentiation and disease state. As such, the regulation of methylation 'types' is often uncoupled. The emerging picture suggests that no approach can accurately detect all biologically important differences in $5 \mathrm{mC}$ variation and distribution in all instances, with this needing to be ascertained on a case-by-case basis. Thus, it is important to clearly elaborate the genomic context and content of DNA methylation being analysed, the sample and developmental stage in which it is being examined and to remember that in most instances, the most common measures are not a true representation of 'global' $5 \mathrm{mC}$ content as orginally defined.
\end{abstract}

\section{Approaches}

There are three general classes of DNA methylation measures. The first is locus/gene-specific analysis, usually at a small number of defined CpG sites in a limited genomic region. The second involves building a profile of DNA methylation by measuring many unique sites across the genome, (genome-wide or genome-scale analysis). The third, referred to as global methylation, is designed to assess the total 5-methylcytosine $(5 \mathrm{mC})$ content (but not $5 \mathrm{hmC}, 5 \mathrm{fC}$ or $5 \mathrm{caC}$ ) within a sample using either direct or surrogate/proxy measures. It has been known for decades that changes in global methylation are a feature of human malignancy [1].

\footnotetext{
* Correspondence: Richard.saffery@mcri.edu.au

${ }^{1}$ Murdoch Childrens Research Institute, 50 Flemington Rd, Parkville, Victoria 3052, Australia

${ }^{2}$ Department of Paediatrics, University of Melbourne, Parkville, Victoria, Australia
}

Global DNA methylation refers to the total level of $5 \mathrm{mC}$ content in a sample relative to total cytosine content. This is usually assessed using HPLC [1-3] but can also be assessed by HPLC coupled tandem mass spectrometry (LC-MS/MS) [4] and high-performance capillary electrophoresis [5]. These methods are the only true measures of global methylation as originally defined but are generally bour intensive and often require large amounts of starting genomic DNA. For example, HPLC measurement of tal $5 \mathrm{mC}$ generally requires several micrograms of starting genomic DNA, whereas more contemporary 'proxy' aproaches can be carried out using less than $100 \mathrm{ng}$ With the advent of highly specific antibodies to $5 \mathrm{mC}$ (

Alt measures rely on the ascertainment of DNA und levels at a subset of genomic sites, with the underlying assumption that these reflect the global measure. The most popular involves the sampling of 
multiple copies of repetitive LINE (long interspersed numerical elements; mainly LINE-1) and SINE (short interspersed numerical elements; mainly Alu), amplified using degenerate primer sequences [6]. Together, these sites comprise upwards of $30 \%$ of human genomic DNA [7], but the actual number of potential sites of methylation within the genome remains lower. Less abundant satellite sequences have also been used to give insights to global methylation status, though these often represent even less of total genomic DNA by content [8]. Other methods use methylation sensitive (e.g. HpaII)/insensitive (MspI) restriction endonucleases [9]. Comparison of resulting genomic digestion patterns can yield insights regarding the level and distribution of $5 \mathrm{mC}$ within the genome, though this also represents a small fraction of total potential sites of DNA methylation. The luminometric methylation assay [10] or LUMA was adapted from these methods that measures fragments by a luminometric extension assay [11] with subsequent pyrosequencing.

An increasingly used proxy measure of overall methylation within a sample is often derived from genome-scale/ wide methylation profiling. This is usually a mean or median methylation value of many thousands to millions of individual methylation values, spread throughout the genome and measured by beadarray, reduced representation, or whole genome bisulphite sequencing approaches.

\section{Considerations for interpretation}

There are several important caveats to using any surrogate markers of global $5 \mathrm{mC}$, primarily associated with the non-uniform nature of methylation within the human genome in association with genomic context. Firstly, when utilising a composite average (mean or median) measure derived from a large number of essentially unique sequences, it is important to note that most genomic DNA methylation is in fact found in repetitive elements scattered throughout the genome, such as transposons and endogenous retrovirus. Similarly, the HpaII restriction site, often used to generate a proxy measure of global methylation, is enriched in highdensity CpG islands comprising only $\sim 12 \%$ of the total restriction sites in the human genome [12].

Secondly, repeat-based measures based on amplification using degenerate primer sequences generally only assess methylation at a subset of LINE or Alu elements, due to the range of sub-families of varying frequency and the large amount of sequence degeneration over time [13]. Although LINE-1 and Alu account for $\sim 17$ and $11 \%$ of the human genome [13], representing $\sim 12$ and $25 \%$ of all CpG dinucleotides respectively [14], only a subset of each can be interrogated by any given technique.

Finally, the mechanism of regulation of DNA methylation at different classes of unique and repetitive DNAs vary and therefore measuring one 'type' of methylation site is unlikely to be representative of global methylation levels. Direct comparison between approaches has been made, with varying results. In some in vitro cell line experiments, reduction in global methylation due to treatment by demethylating agents showed congruent results between Alu, LINE-1 and HPLC but not LUMA. In other cell lines, LINE-1, LUMA and HPLC yielded congruent levels of global hypomethylation. Generally, LINE-1 methylation status appears to correlate with HPLC measures more than Alu or LUMA, but not always, and this does not always correspond to a change in total global $5 \mathrm{mC}$ content [15]. The emerging picture is that no surrogate assay can accurately detect all biologically important differences in global $5 \mathrm{mC}$ content in all instances, with this needing to be ascertained on a case-by-case basis [16-19], particularly in the context of malignancy [20].

A recent comprehensive study explored whether global DNA methylation levels could be inferred from a combined measure of repeat-specific data [21]. Five alternative 'global' methylation approaches based on three technologies were employed including (i) highperformance liquid chromatography followed by mass spectrometry (HPLC-MS) [22] (ii) immunoquantification of global DNA methylation by ELISA [23] and, (iii) bisulfite pyrosequencing of a variety of different repetitive DNA elements (AluYb8/D4Z4/LINE/NBL2) $[6,24-26]$. There was generally less agreement among the global DNA methylation assays across samples than with locus-specific DNA methylation assays, with the least reliable being the ELISA approach. A direct comparison of true global $5 \mathrm{mC}$ measures with average locus-specific (repeat-based) methylation showed a range of correlations, according to cell type and disease state. Interestingly, when combined with machine learning methods, repeat-specific assays reliably predicted sample-specific differences in true global $5 \mathrm{mC}$ levels [21].

\section{Biological relevance}

It is important to note that several measures of 'global' methylation have been reported to vary in response to factors such as age, sex and cell composition. However, findings have been inconsistent. For example, total $5 \mathrm{mC}$, as measured by HPLC in peripheral blood, has been found to be inversely associated with age [27, 28] whereas no association with age was found in analyses of LINE-1 [29, 30], Alu [30] or restriction-enzyme approaches [31], while another study using LUMA reported both gain and loss of methylation over time [32]. Further, other evidence suggests ageing-specific changes in Alu methylation in the absence of LINE-1 change. Such discrepancies indicate the possibility of heterogeneous 
changes of global methylation over time [33]. Indeed, changes in global methylation as measured by LUMA have identified age and tissue-specific effects in rats but not in the CG rich or promoter regions as previously utilised in other LUMA analyses [34]. In addition, age-specific changes are prominent near genes involved in metabolism indicating potential biological feasibility. Conversely, global methylation changes may not track with chronological age but as a result of functional decline [10], though the direction of causality is yet to be ascertained. A potential confounder of ageing-specific changes in global methylation has been linked to dietary composition including alteration in blood lipid profiles [35] and changes in nutritional content [36].

Distinguishing the type of measure employed is important in the case of disease association studies. For example, LINE-1 hypomethylation of peripheral blood, assessed prospectively, has been identified as a risk factor for a range of cancers [37], including bladder cancer [38]. Additionally, greater Alu methylation has been identified as a predictive biomarker for prostate cancer [39]. Increased CpG island DNA methylation in peripheral blood, as measured by LUMA, has been prospectively associated with an increased risk of breast cancer [40]. However, in the same analysis, LINE-1 methylation showed no association. Conversely, LINE-1 methylation varies in some prostate cancers in the absence of any measurable change in global $5 \mathrm{mC}$ content as assessed by HPLC [41].

Variations in the level of repeat-specific methylation are important, as 'repeat-based' hypomethylation has been implicated in the genomic instability associated with tumour progression and outcome [35, 42]. Further, repeat-based hypomethylation within a sample will likely have distinct functional consequences from hypomethylation assessed through largely gene-associated CpG sites, irrespective of the number of such sites assessed. In this way, the definition of global methylation shifts between 'repeat-based' methylation as an assessment of genomic stability to promoter-specific methylation, primarily implicated in gene regulation.

\section{Conclusions}

It is important to clearly elaborate the context of DNA being used to measure methylation levels as different 'types' of DNA methylation are often uncoupled in terms of regulation. Most surrogate or proxy measures do not reflect global methylation (total $5 \mathrm{mC}$ content) as originally defined, and even though changes in repeat-specific measures may accurately reflect changes in global $5 \mathrm{mC}$, this is likely to be system- and disease-specific.

\section{Funding}

RS is funded by a National Health and Medical Research Council (Aust) Senior Research Fellowship and RV by an Australian Postgraduate Award.
The MCRI is funded by the Victorian Government (Australia) Operational Infrastructure Scheme.

Availability of data and materials

Not applicable

Authors' contributions

RS and RV both conceived and wrote the manuscript. Both authors read and approved the final manuscript.

\section{Competing interests}

The authors declare that they have no competing interests.

Consent for publication

Not applicable

Ethics approval and consent to participate

Not applicable

Received: 28 September 2016 Accepted: 4 January 2017

Published online: 13 January 2017

References

1. Gama-Sosa MA, Slagel VA, Trewyn RW, Oxenhandler R, Kuo KC, Gehrke CW, Ehrlich M. The 5-methylcytosine content of DNA from human tumors. Nucleic Acids Res. 1983;11(19):6883-94.

2. Kuo KC, McCune RA, Gehrke CW, Midgett R, Ehrlich M. Quantitative reversed-phase high performance liquid chromatographic determination of major and modified deoxyribonucleosides in DNA. Nucleic Acids Res. 1980; 8(20):4763-76.

3. Wagner I, Capesius I. Determination of 5-methylcytosine from plant DNA by high-performance liquid chromatography. Biochim Biophys Acta. 1981; 654(1):52-6

4. Friso S, Choi SW, Girelli D, Mason JB, Dolnikowski GG, Bagley PJ, Olivieri O,

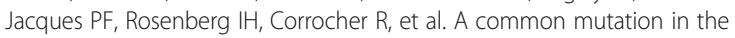
5,10-methylenetetrahydrofolate reductase gene affects genomic DNA methylation through an interaction with folate status. Proc Natl Acad Sci U S A. 2002;99(8):5606-11.

5. Fraga MF, Uriol E, Borja Diego L, Berdasco M, Esteller M, Canal MJ, Rodriguez R. High-performance capillary electrophoretic method for the quantification of 5-methyl 2'-deoxycytidine in genomic DNA: application to plant, animal and human cancer tissues. Electrophoresis. 2002;23(11): 1677-81.

6. Yang AS, Estecio MR, Doshi K, Kondo Y, Tajara EH, Issa JP. A simple method for estimating global DNA methylation using bisulfite PCR of repetitive DNA elements. Nucleic Acids Res. 2004;32(3):e38.

7. Cordaux R, Batzer MA. The impact of retrotransposons on human genome evolution. Nat Rev Genet. 2009;10(10):691-703

8. Rauch T, Li H, Wu X, Pfeifer GP. MIRA-assisted microarray analysis, a new technology for the determination of DNA methylation patterns, identifies frequent methylation of homeodomain-containing genes in lung cancer cells. Cancer Res. 2006:66(16):7939-47.

9. Cedar H, Solage A, Glaser G, Razin A. Direct detection of methylated cytosine in DNA by use of the restriction enzyme Mspl. Nucleic Acids Res. 1979;6(6):2125-32

10. Bellizzi D, D'Aquila P, Montesanto A, Corsonello A, Mari V, Mazzei B, Lattanzio F, Passarino G. Global DNA methylation in old subjects is correlated with frailty. Age. 2012:34(1):169-79.

11. Karimi M, Johansson S, Ekstrom TJ. Using LUMA: a luminometric-based assay for global DNA-methylation. Epigenetics. 2006;1(1):45-8.

12. Fazzari MJ, Greally JM. Epigenomics: beyond CpG islands. Nat Rev Genet 2004;5(6):446-55.

13. Lander ES, Linton LM, Birren B, Nusbaum C, Zody MC, Baldwin J, Devon K, Dewar K, Doyle M, FitzHugh W, et al. Initial sequencing and analysis of the human genome. Nature. 2001:409(6822):860-921.

14. Schmid CW. Alu: structure, origin, evolution, significance and function of one-tenth of human DNA. Prog Nucleic Acid Res Mol Biol. 1996:53:283-319.

15. Lisanti S, Omar WAW, Tomaszewski B, De Prins S, Jacobs G, Koppen G, Mathers JC, Langie SAS. Comparison of methods for quantification of global DNA methylation in human cells and tissues. PLoS ONE. 2013;8(11):e79044. 
16. Cho NY, Kim BH, Choi M, Yoo EJ, Moon KC, Cho YM, Kim D, Kang GH. Hypermethylation of CpG island loci and hypomethylation of LINE-1 and Alu repeats in prostate adenocarcinoma and their relationship to clinicopathological features. J Pathol. 2007;211(3):269-77.

17. Choi IS, Estecio MR, Nagano Y, Do Kim H, White JA, Yao JC, Issa JP, Rashid A. Hypomethylation of LINE-1 and Alu in well-differentiated neuroendocrine tumors (pancreatic endocrine tumors and carcinoid tumors). Mod Pathol. 2007;20(7):802-10.

18. Price EM, Cotton AM, Penaherrera MS, McFadden DE, Kobor MS, Robinson W. Different measures of "genome-wide" DNA methylation exhibit unique properties in placental and somatic tissues. Epigenetics. 2012;7(6):652-63.

19. Weisenberger DJ, Campan M, Long TI, Kim M, Woods C, Fiala E, Ehrlich M, Laird PW. Analysis of repetitive element DNA methylation by MethyLight. Nucleic Acids Res. 2005;33(21):6823-36.

20. Brennan K, Flanagan JM. Is there a link between genome-wide hypomethylation in blood and cancer risk? Cancer Prev Res (Phila). 2012; 5(12):1345-57.

21. Bock C, Halbritter F, Carmona FJ, Tierling S, Datlinger T, Assenov $Y$ Berdasco M, Bergmann AK, Booher K, Busato F, et al. Quantitative comparison of DNA methylation assays for biomarker development and clinical applications. Nat Biotech. 2016;34:726-37.

22. Ehrlich M. DNA hypomethylation in cancer cells. Epigenomics. 2009;1(2):239-59.

23. Kremer D, Metzger S, Kolb-Bachofen V, Kremer D. Quantitative measurement of genome-wide DNA methylation by a reliable and cost-efficient enzyme-linked immunosorbent assay technique. Anal Biochem. 2012;422(2):74-8.

24. Bollati V, Baccarelli A, Hou L, Bonzini M, Fustinoni S, Cavallo D, Byun HM, Jiang J, Marinelli B, Pesatori AC, et al. Changes in DNA methylation patterns in subjects exposed to low-dose benzene. Cancer Res. 2007;67(3):876-80.

25. Choi SH, Worswick S, Byun HM, Shear T, Soussa JC, Wolff EM, Douer D, Garcia-Manero G, Liang G, Yang AS. Changes in DNA methylation of tandem DNA repeats are different from interspersed repeats in cancer. Int J Cancer. 2009;125(3):723-9.

26. Martinez JG, Perez-Escuredo J, Castro-Santos P, Marcos CA, Pendas JL, Fraga MF, Hermsen MA. Hypomethylation of LINE-1, and not centromeric SAT-alpha, is associated with centromeric instability in head and neck squamous cell carcinoma. Cell Oncol (Dordr). 2012;35(4):259-67.

27. Fuke C, Shimabukuro M, Petronis A, Sugimoto J, Oda T, Miura K, Miyazaki T, Ogura C, Okazaki Y, Jinno Y. Age related changes in 5-methylcytosine content in human peripheral leukocytes and placentas: an HPLC-based study. Ann Hum Genet. 2004;68(Pt 3):196-204.

28. Shimabukuro M, Sasaki T, Imamura A, Tsujita T, Fuke C, Umekage T, Tochigi M, Hiramatsu K, Miyazaki T, Oda T, et al. Global hypomethylation of peripheral leukocyte DNA in male patients with schizophrenia: a potential link between epigenetics and schizophrenia. J Psychiatr Res. 2007;41(12):1042-6.

29. Chalitchagorn K, Shuangshoti S, Hourpai N, Kongruttanachok N, Tangkijvanich P, Thong-ngam D, Voravud N, Sriuranpong V, Mutirangura A Distinctive pattern of LINE-1 methylation level in normal tissues and the association with carcinogenesis. Oncogene. 2004;23(54):8841-6.

30. Rusiecki JA, Baccarelli A, Bollati V, Tarantini L, Moore LE, Bonefeld-Jorgensen EC. Global DNA hypomethylation is associated with high serum-persistent organic pollutants in Greenlandic Inuit. Environ Health Perspect. 2008; 116(11):1547-52.

31. Hsiung DT, Marsit CJ, Houseman EA, Eddy K, Furniss CS, McClean MD, Kelsey KT. Global DNA methylation level in whole blood as a biomarker in head and neck squamous cell carcinoma. Cancer Epidemiol Biomarkers Prev. 2007;16(1):108-14.

32. Bjornsson HT, Sigurdsson MI, Fallin MD, Irizarry RA, Aspelund T, Cui H, Yu W, Rongione MA, Ekstrom TJ, Harris TB, et al. Intra-individual change over time in DNA methylation with familial clustering. JAMA. 2008;299(24):2877-83.

33. Zhu ZZ, Hou L, Bollati V, Tarantini L, Marinelli B, Cantone L, Yang AS, Vokonas P, Lissowska J, Fustinoni S, et al. Predictors of global methylation levels in blood DNA of healthy subjects: a combined analysis. Int J Epidemiol. 2012;41(1):126-39.

34. Thompson RF, Atzmon G, Gheorghe C, Liang HQ, Lowes C, Greally JM, Barzilai N. Tissue-specific dysregulation of DNA methylation in aging. Aging Cell. 2010;9(4):506-18.

35. Rodriguez J, Frigola J, Vendrell E, Risques RA, Fraga MF, Morales C, Moreno V, Esteller M, Capella G, Ribas M, et al. Chromosomal instability correlates with genome-wide DNA demethylation in human primary colorectal cancers. Cancer Res. 2006;66(17):8462-9468.
36. Gomes MVM, Toffoli LV, Arruda DW, Soldera LM, Pelosi GG, Neves-Souza RD, Freitas ER, Castro DT, Marquez AS. Age-related changes in the global DNA methylation profile of leukocytes are linked to nutrition but are not associated with the MTHFR C677T genotype or to functional capacities. PLOS ONE. 2012;7(12):e52570.

37. Antelo M, Balaguer F, Shia J, Shen Y, Hur K, Moreira L, Cuatrecasas M, Bujanda L, Giraldez MD, Takahashi M, et al. A high degree of LINE-1 hypomethylation is a unique feature of early-onset colorectal cancer. PLoS One. 2012;7(9):e45357.

38. Wilhelm CS, Kelsey KT, Butler R, Plaza S, Gagne L, Zens MS, Andrew AS, Morris S, Nelson HH, Schned AR, et al. Implications of LINE1 methylation for bladder cancer risk in women. Clin Cancer Res. 2010;16(5):1682-9.

39. Barry KH, Moore LE, Liao LM, Huang WY, Andreotti G, Poulin M, Berndt SI. Prospective study of DNA methylation at LINE-1 and Alu in peripheral blood and the risk of prostate cancer. Prostate. 2015;75(15):1718-25.

40. Xu X, Gammon MD, Hernandez-Vargas H, Herceg Z, Wetmur JG, Teitelbaum SL, Bradshaw PT, Neugut Al, Santella RM, Chen J. DNA methylation in peripheral blood measured by LUMA is associated with breast cancer in a population-based study. FASEB J. 2012;26(6):2657-66.

41. Yegnasubramanian S, Haffner MC, Zhang Y, Gurel B, Cornish TC, Wu Z, Irizarry RA, Morgan J, Hicks J, DeWeese TL, et al. DNA hypomethylation arises later in prostate cancer progression than $\mathrm{CpG}$ island hypermethylation and contributes to metastatic tumor heterogeneity. Cancer Res. 2008;68(21):8954-67.

42. Kim MJ, White-Cross JA, Shen L, Issa JP, Rashid A. Hypomethylation of long interspersed nuclear element-1 in hepatocellular carcinomas. Clin Cancer Res. 2009;22(3):442-9.

\section{Submit your next manuscript to BioMed Central and we will help you at every step:}

- We accept pre-submission inquiries

- Our selector tool helps you to find the most relevant journal

- We provide round the clock customer support

- Convenient online submission

- Thorough peer review

- Inclusion in PubMed and all major indexing services

- Maximum visibility for your research

Submit your manuscript at www.biomedcentral.com/submit

) BioMed Central 